\title{
OVERMACHT DALAM TINDAK PIDANA PenganiayaAn Yang MenYebabkan Korban MENINGgAL DUNIA PERSPEKTIF FIQH JINÂYAH
}

\author{
Muhammad Rizal Fahmi \\ arah.rizal@gmail.com \\ Jl. Jagir Wonokromo No. 140A Surabaya
}

\begin{abstract}
The Judge's ruling in the legal decition of the Lamongan District Court No. 164/Pid.B/2013/PN.LMG on the crime of persecution that causes the death of the victim is regarded true since it has been fulfilled all elements as required by Article 351 Paragraph (3) of Criminal Code as indicted by the public prosecutor. In deciding this case, the judge also considered the testimony of witnesses, the information from the defendant, the facts revealed at the hearing as well as the things that burdensome and relieve the defendant. Therefore, the defendant shall be sentenced for 5 months in prison and does not have to go through due to the imposed conditional sentence. In Islamic criminal law, the case is equated with a semi-deliberate murder and sanctioned by diyât and kafârat in the form of ta'zîr. In this case, the defendant can not be punished because of his self-defense. So that the defendant is free from a criminal liability in Islam.
\end{abstract}

Keywords: Persecution, victim died, Islamic law.

\begin{abstract}
Abstrak: Putusan hukum hakim Nomor: 164/Pid.B/2013/PN.LMG tentang tindak pidana penganiayaan yang mengakibatkan korban meninggal dunia berdasarkan telah terpenuhinya semua unsur-unsur dari pasal 351 ayat (3) KUHP seperti yang didakwakan oleh jaksa penuntut umum. Dalam memutuskan perkara ini hakim juga mempertimbangkan keterangan saksi, keterangan terdakwa, fakta-fakta yang terungkap di persidangan, serta hal yang memberatkan dan meringankan terdakwa. Oleh karena itu, terdakwa dipidana dengan 5 bulan penjara dan tidak perlu menjalaninya dikarenakan dikenakan hukuman bersyarat. Dalam fiqh jinâyah, perkara ini disamakan dengan pembunuhan semi sengaja. Untuk sanksinya yaitu membayar diyat dan kafârat, sedangkan untuk hukuman penggantinya berupa hukuman ta'zîr. Dalam kasus ini, para terdakwa meskipun telah melakukan perbuatan tersebut, namun tidak bisa dikenakan hukuman tersebut, karena adanya unsur pembelaan diri, sehingga terbebas dari pertanggungjawaban pidana dalam Islam.
\end{abstract}

Kata Kunci: Penganiayaan, meninggal dunia, Hukum Islam. 


\section{Pendahuluan}

Negara Indonesia merupakan negara yang berdasarkan hukum (rechtsstaat) bukan berdasarkan kekuasaan (machtstaat). Hal ini dapat dengan jelas ditetapkan dalam penjelasan Undang-undang Dasar 1945, di dalam Undang-undang Dasar Negara 1945 Pasal 1 Ayat (3) pun menentukan secara tegas bahwa negara Indonesia adalah negara hukum. Sejalan dengan ketentuan tersebut, maka salah satu prinsip negara hukum adalah adanya jaminan kesederajatan bagi setiap orang di depan hukum (equality before the law). Oleh karena itu, setiap orang berhak atas pengakuan, jaminan, perlindungan, kepastian hukum yang adil dan perlakuan sama di depan hukum.

Hukum adalah rangkaian peraturan-peraturan mengenai tingkah laku orang-orang sebagai anggota masyarakat, sedangkan satu-satunya tujuan dari hukum ialah mengadakan keselamatan, kebahagiaan dan tata tertib di dalam masyarakat. ${ }^{1}$ Namun dengan adanya statemen di atas bukan berarti seseorang tidak akan melakukan suatu tindak kejahatan yang merugikan orang lain.

Berbagai bentuk dari pidana yang timbul di dalam masyarakat dirumuskan dan diatur dalam ketentuan Kitab Undang-undang Hukum Pidana Buku Ke-II, yang memuat tentang kejahatan serta ketentuanketentuan yang ada dalam KUHP. Dalam hukum pidana positif yang dapat dikenakan hukuman hanyalah tindakan-tindakan yang telah diatur dengan tegas dan dinyatakan dapat dikenai hukuman oleh undangundang.

Seiring berkembangnya zaman dan teknologi, maka semakin berkembanglah pula angka kejahatan yang terjadi sehingga menimbulkan keresahan pada masyarakat. Di antara berbagai macam kejahatan, adalah penganiayaan yang mengakibatkan korbannya meninggal dunia.

Seperti yang terjadi di Dusun Waduk desa Tlemang kecamatan Ngimbang kabupaten Lamongan dalam putusan Pengadilan Negeri Lamongan NO:164/PID.B/2013/PN.LMG. Dikisahkan pada putusan Pengadilan Negeri Lamongan, seorang warga lamongan yang sedang kambuh penyakit gangguan jiwanya mengamuk dan melempari genting rumah Rajak dan suliyah, kemudian Rajak dan Suliyah keluar dan melihat yang melempari rumah. Melihat yang melempari rumah adalah Matalim yang lagi kambuh gangguan jiwanya, Rajak dan Suliyah cepat-

\footnotetext{
${ }^{1}$ Wirjono Prodjodikoro, Asas-Asas Hukum Pidana di Indonesia (Bandung: PT Eresco, 1486), 14.
} 
cepat masuk kembali ke rumahnya. Selang beberapa lama kemudian, Matalim datang ke rumah terdakwa dan menggedor-gedor rumah korban, mengetahui hal itu Rajak langsung menahan pintu samping rumah, karena terlalu kuat, Rajak terjatuh dan Matalim berusaha mengayunkan sabit ke arah Rajak. Melihat hal itu, Suliyah memukul Matalim dengan pipa kecil ke arah Matalim, kemudian Matalim mengejar Suliyah sehingga Rajak juga memukul Matalim dengan cengkal pintu ke arah kepala Matalim. Kemudian Rajak dan Suliyah meminta tolong kepada para tetangga untuk membawa Matalim ke rumah sakit. Matalim meninggal dunia 5 hari kemudian setelah dirawat intensif di rumah sakit RSUD Ngimbang. Korban diduga meninggal akibat dari cedera otak berat akibat penganiayaan itu. Dalam kasus ini Rajak dan Suliyah tidak bermaksud menghilangkan nyawa Matalim, namun pada kenyataannya Matalim meninggal beberapa hari setelah penganiayaan akibat luka yang di dapat.

Berdasarkan uraian kasus di atas, jaksa penuntut umum menuntut terdakwa dengan dakwaan tunggal melanggar ketentuan pasal 351 (3) KUHP. Setelah mendengar tuntutan jaksa penuntut umum, majlis hakim menjatuhkan putusan terhadap kedua terdakwa yang terbukti secara sah dan meyakinkan bersalah melakukan tindak pidana penganiayaan yang menyebabkan korban meninggal dunia, serta menjatuhkan pidana penjara 5 bulan penjara dan membebankan biaya perkara kepada masing-masing terdakwa sebesar Rp 2.500,00. Namun pada putusan tersebut hakim memerintahkan bahwa pidana tersebut tidak perlu dijalani, kecuali kalau di kemudian hari dengan putusan hakim yang telah berkekuatan hukum tetap diberikan perintah lain atas alasan para terdakwa sebelum atau sesudah percobaaan selama 8 (Delapan) bulan terakhir telah melakukan sesuatu tindak pidana.

Dalam KUHP penganiayaan dijelaskan dalam bab XX yang terdiri dari:

Penganiayaan berdasarkan (Pasal 351 KUHP) yang meliputi; Penganiayaan biasa $\mathrm{b}$. Penganiayaan yang menimbulkan luka berat $\mathrm{c}$. Penganiayaan yang menyebabkan orangnya mati. Penganiayaan ringan (pasal 352 KUHP), Penganiayaan berencana (pasal 353 KUHP), 
Penganiayaan berat (pasal 354 KUHP), Penganiayaan berat dan berencana (pasal 355 KUHP) $)^{2}$.

Dalam KUHP tidak ada penjelasan mengenai definisi penganiayaan. Secara umum, tindak pidana terhadap tubuh disebut penganiayaan. Menurut ilmu pengetahuan, penganiayaan ialah dengan sengaja minimbulkan (leed) rasa sakit, luka atau merusak kesehatan orang lain ${ }^{3}$.

R. Soesilo memberikan contoh dengan apa yang dimaksud dengan "perasaan tidak enak", "rasa sakit", "luka", dan "merusak kesehatan": "Perasaan tidak enak" misalnya mendorong orang terjun ke kali sehingga basah, menyuruh orang berdiri di terik matahari, dan sebagainya. "Rasa sakit" misalnya menyubit, mendupak, memukul, menempeleng, dan sebagainya. "Luka" misalnya mengiris, memotong, menusuk dengan pisau dan lain-lain. "Merusak kesehatan" misalnya orang sedang tidur, dan berkeringat, dibuka jendela kamarnya, sehingga orang itu masuk angin ${ }^{4}$.

Menurut R. Soesilo, tindakan-tindakan di atas harus dilakukan dengan sengaja dan tidak dengan maksud yang patut atau melewati batas yang diizinkan. Umpamanya, seorang dokter gigi mencabut gigi dari pasiennya. Sebenarnya ia sengaja menimbulkan rasa sakit, akan tetapi perbuatannya itu bukan penganiayaan, karena ada maksud baik (mengobati). Seorang bapak dengan tangan memukul anaknya di arah pantat, karena anak itu nakal. Inipun sebenarnya sengaja menyebabkan rasa sakit, akan tetapi perbuatan itu tidak masuk penganiayaan, karena ada maksud baik (mengajar anak). Meskipun demikian, maka kedua peristiwa itu apabila dilakukan dengan "melewati batas-batas yang diizinkan", misalnya dokter gigi tadi mencabut gigi sambil bersenda gurau dengan isterinya, atau seorang bapak mengajar anaknya dengan memukul memakai sepotong besi dan dikenakan di kepalanya, maka perbuatan ini dianggap pula sebagai penganiayaan ${ }^{5}$.

Hukum pidana Islam sering disebut dalam fiqh dengan istilah jinâyah atau jarîmah. Jinâyah dalam istilah hukum sering disebut dengan

\footnotetext{
${ }^{2}$ Leden Marpaung, Tindak Pidana Terhadap Nyawa dan Tubuh (Jakarta: SInar Grafika, Cetakan III. 2005), 50.

${ }^{3}$ Soeharto HM, Hukum Pidana Materiil Unsur-unsur Obyektif Sebagai dasar Dakwaan (Jakarta: Sinar Grafika, 1993), 36.

${ }^{4} \mathrm{R}$ Soesilo, KUHP serta komentar lengkap (Bogor: Politea, t.th.), 245.

${ }^{5}$ Ibid., 247.
} 
delik atau tindak pidana. Jinâyah merupakan bentuk verbal noun (masdar) dari kata janâ. Secara etimologi janâ berarti berbuat dosa atau salah, sedangkan jinâyah diartikan perbuatan dosa atau perbuatan salah. Secara terminologi, kata jinâyah mempunyai beberapa pengertian, seperti yang diungkapkan oleh Abd al-Qadir Awdah bahwa jinâyah adalah perbuatan yang dilarang oleh shara', baik perbuatan itu mengenai jiwa, harta benda, atau lainnya ${ }^{6}$.

Menurut A. Jazuli, pada dasarnya pengertian dari istilah jinâyah mengacu kepada hasil perbuatan seseorang. Biasanya pengertian tersebut terbatas pada perbuatan yang dilarang. Di kalangan fuqaha, perkataan jinâyah berarti perbuatan perbuatan yang dilarang oleh shara'. Meskipun demikian, pada umunya fuqaha menggunakan istilah tersebut hanya untuk perbuatan perbuatan yang terlarang menurut shara'. Fuqaha menggunakan istilah tersebut hanya untuk perbuatan-perbuatan yang mengancam keselamatan jiwa, seperti pemukulan, pembunuhan dan sebagainya. Selain itu, terdapat fuqaha yang membatasi istilah jinâyah kepada perbuatan perbuatan yang diancam dengan hukuman hudûd dan qisâs, tidak temasuk perbuatan yang diancam dengan ta'zîr. Istilah lain yang sepadan dengan istilah jinâyah adalah jarîmah, yaitu larangan larangan shara' yang diancam Allah dengan hukuman had atau ta'zîr.

Sebagian fuqaha menggunakan kata jinâyah untuk perbuatan yang yang berkaitan dengan jiwa atau anggota badan, seperti membunuh, melukai dan lain sebagainya. ${ }^{8}$ Perbuatan yang diancam dengan hukuman qisâs dan diyât. Baik qisâs maupun diyât merupakan hukuman yang telah ditentukan batasannya, tidak ada batas terendah dan tertinggi tetapi menjadi hak perorangan (si korban dan walinya), ini berbeda dengan hukuman had yang menjadi hak Allah semata. Penerapan hukuman qisâs diyât ada beberapa kemungkinan, seperti hukuman qisâs bisa berubah menjadi hukuman diyât, hukuman diyât apabila dimaafkan akan menjadi hapus. Yang termasuk dalam kategori jarîmah qisâs diyât antara

\footnotetext{
6 http;//elanlan.wordpress.com/2009/10/22/memahami-kedudukan-azir-dalam-fiqh-jinayah, diakses pada 4 juli 2014.

7 'Abdul 'Azhim bin Badawi al-Khalafi, Al-Wajiz Fi Fiqhis Sunnah Wal Kitabil 'Aziz, atau Al-Wajiz, Ensiklopedi Fikih Islam dalam Al-Qur'an dan As-Sunnah Ash-Shahihah (Pustaka As-Sunnah), 853 873.

${ }^{8}$ Ahmad Wardi Muslich, Pengantar dan Asas Hukum Pidana Islam (Fiqih Jinayah) (Jakarta: Sinar Grafika, 2004), 1.
} 
lain pembunuhan sengaja, pembunuhan semi sengaja, pembunuhan keliru, penganiayaan sengaja dan penganiayaan salah?

Asas dasar dari pertanggungjawaban pidana adalah tiada hukuman tanpa adanya kesalahan dan perbuatan terlarang. Adanya pertanggung jawaban pidana sebenarnya dikarenakan telah dilakukannya suatu perbuatan yang dilarang. Jika perbuatan itu dilakukan, namun pelakunya tidak mempunyai pengetahuan dan pilihan, maka pertanggungjawabannya ada, namun si pelaku akan terhapus dari penjatuhan hukuman ${ }^{10}$.

Dalam keadaan tertentu terkadang suatu perbuatan yang dilakukan oleh seseorang dapat berujung pada terjadinya tindak pidana, walaupun orang tersebut tidak menghendaki tindak pidana. Dengan kata lain, tindak pidana dapat terjadi adakalanya seseorang tidak dapat menghindari karena sesuatu yang berasal dari luar dirinya. Faktor luar tersebut membuat seseorang tidak dapat berbuat lain sehingga mengakibatkan kesalahannya terhapus. ${ }^{11}$

Pertanggungjawaban pidana dapat dinyatakan hapus, karena ada kaitannya dengan perbuatan yang terjadi atau kaitannya hal-hal yang terjadi menurut keadaan bagi pelaku. Dalam keadaan yang pertama ini adalah perbuatan yang dilakukan tersebut merupakan perbuatan yang mubah (dalam agama tidak ada pelarangan karena hukum asal). Sedangkan perbuatan yang kedua adalah perbuatan yang dilakukan ini merupakan perbuatan yang terlarang, namun pelaku tidak diberi hukuman karena ada suatu keadaan pada si pelakuyang dapat terhindar dari hukuman. Kedua perbuatan ini (perbuatan dan pelaku) dalam kaidah agama disebut asbâb al-ibâhah dan asbâb raf al-uqûbah. ${ }^{12}$

Penganiayaan yang mengakibatkan kematian merupakan tindak pidana yang bisa dibilang jarang terjadi, tindak pidana ini sangat berbeda dengan pembunuhan sengaja meskipun sama-sama menghilangkan nyawa korban. Sanksi tindak pidana penganiayaan yang mengakibatkan kematian dengan pembunuhan sengaja sangat berbeda, baik ditinjau

\footnotetext{
9 http//boxriborn.blogspot.com/2013/08/pengertian-dan-macam-macam-jinayah_5383.html?m= diakses tgl 6 Juli 2014.

10 Usamah, "Pertanggungjawaban Pidana Perspektif Hukum Islam", Tesis (Sumatera: Universitas Sumatera Utara, 2008), 102.

${ }^{11}$ Ibid., 103.

${ }^{12}$ Ahmad Wardi Muslich, Pengantar dan Asas Hukum Pidana Islam..., 85.
} 
dalam hukum pidana Islam maupun dalam hukum pidana positif dalam KUHP.

Perbuatan para tersangka oleh hakim dikenakan hukuman 5 bulan penjara, dan para tersangka juga tidak perlu untuk menjalani hukuman tersebut, padahal hukuman untuk perbuatan tindak pidana penganiayaan yang mengakibatkan korban meninggal dunia dalam pasal 351 ayat (3) "Jika mengakibatkan mati, diancam dengan pidana penjara paling lama 7 tahun". Berdasarkan uraian di atas, penulis akan menganalisis permasalahan tersebut lebih jauh lagi dengan menuangkan dalam tulisan ini.

\section{Penganiayaan dalam Fiqh Jinâyah}

Kata penganiayaan dalam istilah hukum Islam dapat diartikan dengan kata jarîmah dalam larangan shara' yang diancam oleh Allah swt dengan hukuman had atau ta'zîr. Istilah jarîmah mempunyai kandungan arti yang sama dengan kata jinâyah, dalam bahasa Indonesia sering disebut dengan istilah pidana delik atau tindak pidana. Jinâyah adalah perbuatan yang dilarang oleh Allah swt, baik perbuatan itu merugikan jiwa, harta, atau lainnya ${ }^{13}$.

Macam-macam pelukaan antara lain:

a. Pelukaan pada badan atau organ tubuh (al-jurh) yaitu ${ }^{14}$ :

Pelukaan yang dilakukan oleh seseorang bilamana seseorang merusak anggota tunggal atau yang berpasangan milik orang lain, maka ia wajib membayar diyât sepenuhnya. Dan bilamana ia merusak salah satu dari anggota yang berpasangan maka ia wajib membayar diyât setengah.

Manusia mempunyai organ-organ tubuh, di antaranya ada yang merupakan organ tunggal, seperti hidung lisan/lidah dan penis. Dan juga ada organ-organ yang berpasangan, seperti kedua mata, kedua daun telinga, kedua bibir, kedua janggut, kedua tangan, kedua kaki, kedua belah pelir, kedua buah dada wanita, kedua buah dada kaki, kedua pantat, dan kedua bibir kemaluan wanita, dan ada juga organ-organ yang lebih banyak dari itu.

b. Pelukaan pada muka dan kepala (Al-Shajjal)

\footnotetext{
13 A. Djazuli, Figh Jinayah (Upaya Menanggulangi Kejahatan dalam Islam) (Jakarta: PT Raja Grafindo Persada, 2000).

${ }^{14}$ Sayyid Sabiq, Fiqh al-Sunnah, terj. A. Ali, Fiqih Sunnah jilid 10, 106-107.
} 
Pelukaan al-shajjal ialah pelukaan yang dilakukan seseorang yang mengenai batok kepala atau muka dan kepala.

Sedangkan untuk jenis-jenis pelukaan ada 10 antara lain $^{15}$ :

a) al-Kharishah, adalah luka yang hanya sedikit menembus kulit.

b) al-Badhi'ah, adalah luka yang menyentuh daging sesudah kulit.

c) ad-Dâmiyah/Ad-Damigad, adalah luka yang mengeluarkan darah.

d) al-Mutalâhimah, adalah luka yang masuk ke daging.

e) as-Simhâq, adalah luka yang menyisakan antara luka dalam dengan tulang hanya selaput tipis.

f) al-Muwadahah, adalah luka yang sampai ke tulang sehingga tampak tulangnya.

g) al-Hasmiyah, adalah luka yang sampai mematahkan tulang dan meremukannya.

h) al-Munqilah, adalah luka yang sampai ke tulang dan mematahkannya sehingga tergeser dari tempatnya.

i) al-Ma'mûmah, adalah luka yang sampai kepada selaput batok kepala.

j) al-Jârifah, adalah luka yang dalam ${ }^{16}$.

Jenis-jenis hukuman pada pelaku penganiayaan :

a. Qisâs yaitu pembalasan yang serupa dengan perbuatan atau pengerusakan anggota badan atau menghilangkan manfaatnya dengan pelanggaran yang dibuatnya.

b. Diyât ialah harta benda yang wajib ditunaikan oleh sebab tindakan kejahatan, kemudian diberikan kepada si korban kejahatan atau walinya. Diyât meliputi denda sebagai pengganti qisâs dan denda selain qisâs. Diyât ini disebut dengan nama al-'aql (pengikat) karena bilamana seseorang membunuh orang lain, ia harus membayar diyât serupa unta-unta, kemudian unta-unta tersebut di ikat dihalaman rumah wali si korban untuk diserahkan sebagai tebusan darah ${ }^{17}$.

c. Ta'zîr adalah hukuman yang bersifat edukatif yang ditentukan oleh hakim atas pelaku tindak pidana atau pelaku perbuatan maksiat yang hukumnya belum ditentukan oleh syariat, atau dengan kata lain kepastian hukumnya belum $\mathrm{ada}^{18}$.

\footnotetext{
${ }^{15}$ Ibid., 112.

${ }^{16}$ Ibid., 113

17 Ibid., 90-91.

${ }^{18}$ Ibid., 151.
} 


\section{Konsep Pembunuhan dalam Hukum Islam}

Pembunuhan dalam bahasa Indonesia diartikan dengan proses, perbuatan atau cara membunuh. Sedangkan pengertian membunuh adalah mematikan menghilangkan (menghabisi; mencabut) nyawa. ${ }^{19}$

Seperti yang dikutip oleh Ahmad Wardi Muslich Abdul Qadir Audah memberikan definisi pembunuhan sebagai berikut:

"Pembunuhan adalah perbuatan manusia yang menghilangkan kehidupan yakni pembunuhan itu adalah menghilangkan nyawa manusia dengan sebab perbuatan manusia yang lain." ${ }^{20}$

Macam-Macam Pembunuhan

a. Pembunuhan sengaja

Yang dimaksud dengan pembunuhan disengaja atau qatl al'amd adalah suatu perbuatan yang disertai niat (direncanakan) sebelumnya untuk menghilangkan nyawa orang lain. Dengan menggunakan alat-alat yang dapat mematikan, seperti golok, kayu runcing, besi pemukul, dan sebagainya, dengans sebab-sebab yang tidak dibenarkan oleh ketentuan Hukum. ${ }^{21}$

Unsur-unsur pembunuhan sengaja :

1) Korban yang dibunuh adalah manusia yang hidup.

2) Kematian adalah hasil dari perbuatan pelaku.

3) Pelaku tersebut menghendaki adanya kematian.

4) Pembunuhan menyerupai sengaja.

b. Pembunuhan semi sengaja

Menurut Hanafiyah, seperti yang dikutip Abdul Qadir Audah, pengertian pembunuhan menyerupai sengaja adalah suatu pembunuhan dimana pelaku sengaja memukul korban dengan tongkat, cambuk, batu, tangan atau benda lain yang mengakibatkan kematian. ${ }^{22}$

Menurut Syafi'iyah, pengertian pembunuhan menyerupai sengaja adalah suatu pembunuhan di mana pelaku sengaja dalam perbuatan, tetapi keliru dalam pembunuhan. ${ }^{23}$

Unsur-unsur pembunuhan menyerupai sengaja:

1) Adanya perbuatan dari pelaku yang mengakibatkan kematian

\footnotetext{
${ }^{19}$ Ahmad Wardi Muslich, Hukum Pidana Islam (Fiqih Jinayah) (Jakarta: SinarGrafika, 2004), 136.

${ }^{20}$ Ibid., 136.

${ }^{21}$ Rahmat Hakim, Hukum Pidana Islam (Bandung: CV. PustakaSetia, 2000), 118.

${ }^{22}$ Ahmad Wardi Muslich, Hukum Pidana Islam (Fiqih Jinayah), 141.

${ }^{23}$ Ibid., 142.
} 
2) Adanya kesengajaan dalam melakukan perbuatan

3) Kematian adalah akibat perbuatan pelaku

c. Pembunuhan karena kesalahan

Pengertian pembunuhan kesalahan, sebagaimana dikemukakan Sayyiq Sabiq adalah apabila sesorang mukallaf melakukan perbuatan yang dibolehkan untuk dikerjakan, seperti menembak binatang buruan atau membidik suatu sasaran, tetapi kemudian mengenai orang yang dijamin keselamatannya dan membunuhnya. ${ }^{24}$

Sedangkan Wahbah Zuhaili mendefinisikan pembunuhan kesalahan adalah pembunuhan yang terjadi tanpa maksud melawan hukum, baik dalam perbuatannya maupun dalam objeknya. ${ }^{25}$

Dari definisi yang dikemukakan di atas, dapat diambil intisari bahwa dalam pembunuhan karena kesalahan, sama sekali tidak ada unsur kesengajaan untuk melakukan perbuatan yang dilarang. Dan tindak pembunuhan terjadi karena kurang hati-hati atau karena kelalaian pelaku, perbuatan yang sengaja dilakukan sebenarnya adalah perbuatan mubah tetapi karena kelalaian pelaku dari perbuatan mubah ini timbul suatu akibat yang dikatagorikan sebagai tindak pidana. Dalam hal ini pelaku dipermasalahkan, karena ia lalai atau kurang hati-hati sehingga hilangnya nyawa orang lain.

Unsur-unsur dari pembunuhan karena kesalahan antara lain:

1) Adanya perbuatan yang mengakibatkan matinya korban.

2) Perbuatan tersebut terjadi karena kekeliruan.

3) Adanya sebab akibat antara kekeliruan dan kematian.

Sanksi Pembunuhan:

a. Pembunuhan sengaja

Dalam hukum Islam, hukuman pokok bagi pembunuhan sengaja adalah qisâs, apabila keluarga korban menghapus hukuman pokok ini hukuman penggantinya adalah berupa hukuman diyât, yaitu dengan membayar denda berupa seratus ekor unta yang terdiri dari 30 ekor unta hiqqah ( umur 3-4tahun), 30 ekor unta jadha'ah (umur 4-5 tahun) dan 40 unta yang sedang bunting, selain itu diyât dapat dilakukan dengan membayar diyât 200 ekor sapi. Atau dua ribu kambing, atau uang emas seribu dinar, atau uang perak sebesar dua

24 Ibid., 143.

25 Ibid., 143. 
belas ribu dirham. ${ }^{26}$ Diyât pun seandainya bila dimaafkan dapat dihapuskan dan sebagai penggantinya, hakim menjatuhkan hukuman ta'zîr, dalam memberikan hukuman ta'zîr, hakim diberi kebebasan untuk memilih mana yang lebih maslahat, setelah mempertimbangkan berbagai aspek yang berkaitan dengan tindak pidana yang dilakukan oleh pelaku. Jadi, qisâs sebagai hukuman pokok mempunyai dua hukuman pengganti, yaitu diyât dan $\operatorname{ta}^{\prime} z \hat{i}^{27}$. Di samping hukuman pokok dan pengganti, terdapat pula hukuman tambahan untuk pembunuhan sengaja, yaitu penghapusan hak waris dan wasiat.

b. Pembunuhan semi sengaja

Hukuman pokok pembunuhan semi sengaja adalah diyât dan kafârat. Diyât dalam pembunuhan ini sama dengan diyât dalam pembunuhan sengaja, baik dalam jenis kadar, amupun pemberatannya. Hukuman kafarrat berupa memerdekakan budak mukmin, atau dengan puasa dua bulan berturut-turut. Hukuman pengganti dari pembunuhan semi sengaja adalah ta'zîr yang penentuannya diserahkan kepada hakim ${ }^{28}$. Hukuman tambahannya adalah terhalangnya menerima warisan dan wasiat. ${ }^{29}$

c. Pembunuhan kesalahan

Hukuman pokok pada pembunuhan kesalahan adalah diyât dan kafârat diyât pada pembunuhan tidak sengaja berupa seratus ekor unta yang terdiri dari 20 ekor unta betina umur 1-2 tahun, 20 ekor unta jantan umur 1-2 tahun, 20 ekor unta betina umur 2-3 tahun, 20 ekor unta hiqqah dan 20 ekor unta jadha'ah. Hukuman kafârah berupa memerdekakan hamba sahaya mukmin atau berpuasa 2 bulan berturut-turut. Hukuman penggantinya adalah puasa dan ta'zîr dan hukuman tambahannya adalah hilangnya hak wasiat dan mendapatkan warisan. ${ }^{30}$

\section{Hapusnya Pertanggungjawaban dalam Fiqh Jinâyah}

Pertanggungjawaban pidana dapat hapus karena hal-hal yang bertalian dengan perbuatan atau karena hal-hal yang bertalian dengan

\footnotetext{
${ }^{26}$ Ibid., 169.

${ }^{27}$ Makhus Munajat, Dekonstruksi Hukum Pidana Islam (Jogjakarta: Logung Pustaka, 2004), 172.

${ }^{28}$ Ahmad Wardi Muslich, Hukum Pidana Islam (Fiqih Jinayah), 173-174.

${ }^{29}$ Makhus Munajat, Dekontruksi Hukum Pidana Islam, 173.

${ }^{30}$ Ahmad Wardi Muslich, Hukum Pidana Islam (Fiqih Jinayah), 175.
} 
pelaku. Sebab-sebab yang berkaitan dengan perbuatan yang diperbolehkan disebut asbâb al-ibâhah. Sedangkan sebab-sebab yang berkaitan dengan keadaan pelaku disebut asbâb raf al-uqûbah. Abdul Qadir Audah sebagaimana dikutip Ahmad Wardi Muslich mengemukakan bahwa sebab diperolehkannya perbuatan yang terlarang terdapat enam macam yaitu ${ }^{31}$ :

a. Pembelaan yang sah

b. Pendidikan dan pengajaran

c. Pengobatan

d. Permainan olahraga

e. Hapusnya jaminan keselamatan

f. Menggunakan wewenang dan melaksanakan kewajiban bagi pihak yang berwajib.

Deskripsi Pmbelaan Diri dengan Tindakan Penganiayaan yang Menyebabkan Korban Meninggal Dunia dalam Putusan Pengadilan Negeri Lamongan No : 164/Pid.B/2013/PN LMG.

Perbuatan terdakwa 1 bersama terdakwa II pada hari minggu tanggal 13 januari 2013 sekira pukul 13.00 WIB atau setidak-tidaknya pada suatu waktu dalam bulan Januari tahun 2013 bertempat di Dusun Waduk RT 01 RW 03 Desa Tlemang Kecamatan Ngimbang Kabupaten Lamongan, mereka yang melakukan, yang menyuruh melakukan dan yang turut serta melakukan perbuatan, dengan sengaja melakukan penganiayaan terhadap saksi korban Matalim yang menyebabkan saksi korban meninggal dunia. Perbuatan tersebut dilakukan terdakwa dengan cara berikut:

Pada waktu dan tempat sebagaimana tersebut diatas, berawal ketika terdakwa I sedang berada di dalam rumah bersama dengan terdakwa II kemudian mendengar seseorang yang melempari pintu rumah dan genting, kemudian terdakwa I dan terdakwa II keluar rumah dan melihat yang melempari rumah dan genting rumahnya adalah saksi korban yang saat itu sakit stresnya kambuh. Selanjutnya, terdakwa I bersama dengan terdakwa II cepat-cepat masuk ke dalam rumah dan menutup rapat pintu depan dan pintu samping, selang beberapa lama saksi korban datang ke rumah terdakwa I dengan membawa senjata tajam berupa sabit dengan cara menggedor-gedor pintu samping sambil

\footnotetext{
${ }^{31}$ Ahmad Wardi Muslich, Pengantar dan Asas Hukum Pidana Islam (Fiqih Jinayah), 85.
} 
mendorong. Mengetahui hal tersebut, terdakwa I langsung menahan pintu samping rumah dari dalam dengan menggunakan cengkal pintu, namun karena tenaga saksi korban terlalu kuat akhirnya terdakwa I terjatuh ke belakang sambil memegang kayu cengkal pintu. Setelah itu saksi korban masuk dan langsung mengayunkan sabit ke arah terdakwa I, namun ditangkis oleh terdakwa I dengan menggunakan kayu cengkal pintu. Melihat kejadian tersebut, terdakwa II memukul saksi korban dengan menggunakan pipa kecil ke arah punggung sebanyak 3 kali lalu saksi korban berbalik arah memukul terdakwa II seketika itu terdakwa I langsung memukul saksi korban dengan menggunakan kayu cengkal pintu ke arah kepala belakang korban sebanyak 1 kali. Pukulan terdakwa I menyebabkan sabit yang dipegang saksi korban terjatuh dan saksi korban sendiri sempoyongan dan didorong oleh terdakwa I hingga terjatuh dan kepala saksi korban terbentur almari. Selanjutnya terdakwa I mengambil sabit saksi korban sambil ketakutan dan bersembunyi di dapur, sedangkan terdakwa II lari ke depan rumah sambil berteriakteriak minta tolong kepada warga kemudian datang Saksi I, saksi II dan saksi III untuk menolong saksi korban selanjutnya warga dan perangkat desa membawa saksi korban ke rumah sakit Ngimbang.

Bahwa akibat pukulan dan benturan almari menyebabkan saksi korban mengalami luka pada kepala mengeluarkan darah dan saksi korban tidak sadarkan diri.

Bahwa berdasarkan hasil visum et Repertum No./ 449/43/413.105/2013 tanggal 14 Januari 2013 dari RSUD Ngimbang yang ditandatangani oleh dokter dengan kesimpulan saksi korban dalam keadaan tidak sadar reflek pupil menurun, terdapat luka robek pada kepala bagian kiri P:7 cm, kepala bagian kiri terdapat luka memar dan robek $2 \mathrm{~cm}$ (kemungkinan benturan benda tumpul).

Bahwa berdasarkan hasil visum et Repertum No./ 449/43/413.105/2013 tanggal 14 Januari 2013 dari RSUD Ngimbang yang ditandatangani oleh dokter dengan kesimpulan saksi korban dinyatakan meninggal dunia disebabkan cedera otak berat, setelah mendapatkan perawatan intensif selama 5 hari di ICU RSUD Ngimbang. 
Dasar Pertimbangan Hukum Hakim tentang Tindak Pidana Penganiayaan yang Menyebabkan Korban Meninggal Dunia dalam Putusan Pengadilan Negeri Lamongan No:164/Pid.B/2013/PN LMG.

Menimbang, bahwa berdasarkan keterangan para saksi, keterangan terdakwa, bukti surat dan barang bukti serta adanya petunjuk di persidangan maka diperoleh fakta-fakta yuridis sebagai berikut:

1. Bahwa benar pada hari minggu tanggal 13 Januari 2013 sekira jam 13.00 WIB. Di rumah para terdakwa di Dusun Waduk Desa Tlemang Kecamatan Ngimbang Kabupaten Lamongan, terdakwa I dan terdakwa II telah memukul korban.

2. Bahwa benar awalnya korban Matalim yang sedang kambuh gangguan jiwanya, sedang bertengkar dengan saudaranya yang menjadi saksi I, kemudian ditinggal pergi oleh saksi I dan selanjutnya korban pergi menuju rumah terdakwa dan melempari rumah para terdakwa.

3. Bahwa benar kemudian korban menuju pintu samping rumah para terdakwa dan langsung mendobrak pintu yang telah dikunci dengan cengkal pintu dimana terdakwa I sudah berada di belakang pintu seketika terjatuh karena pintu berhasil dibuka oleh korban .

4. Bahwa benar kemudian terdakwa II mengetahui posisi terdakwa I terjatuh dan korban membawa sebilah sabit dan mengayunkannya kepada terdakwa I, lalu terdakwa II memukul korban dengan paralon, selanjutnya korban berusaha memukul terdakwa II dan mengetahui hal tersebut, terdakwa I langsung memukul korban menggunakan kayu cengkal pintu, sehingga korban Matalim terjatuh dan mengeluarkan darah.

5. Bahwa benar akibat perbuatan para terdakwa, korban mengalami luka berat pada kepala dan setelah dirawat intensif di Rumah Sakit selam 5 (lima) hari kemudian korban meninggal dunia.

6. Bahwa benar visum et Repertum No./ 449/43/413.105/2013 tanggal 14 Januari 2013 dari RSUD Ngimbang yang ditandatangani oleh dokter dengan kesimpulan: telah diperiksa seorang korban laki-laki umur 48 tahun, jenis kelamin laki-laki, pekerjaan PNS, alamat Dusun Waduk Desa Tlemang Kecamatan Ngimbang Kabupaten Lamongan, pada pemeriksaan korban dalam keadaan tidak sadar (COMA), reflek pupil menurun, terdapat luka robek pada kepala 
bagian kiri P.7 cm, kepala bagian kiri terdapat luka memardan robek $2 \mathrm{~cm}$ (kemungkinan Benturan benda tumpul) dan visum El Repertum No.449/413.105/2013 tertanggal 17 januari 2013 dari rumah sakit umum daerah Ngimbang Lamongan yang ditandatangani dokter dengan kesimpulan: telah diperiksa seorang laki-laki, umur 48 tahun. Jenis kelamin laki-laki, pekerjaan PNS, alamat Dusun Waduk Desa Tlemang Kecamatan Ngimbang Kabupaten Lamongan. Pada pemerikasaan Jam 09.00 WIB tanggal 17 januari 2013 korban dinyatakan sudah meninggal disebabkan cedera otak berat setelah mendapat perawatan intensif selama 5 hari di ICU RSUD Ngimbang.

Menimbang, bahwa berdasarkan fakta-fakta hukum sebagaimana terurai di atas, kini akan dipertimbangkan mengenai apakah perbuatan para terdakwa telah memenuhi unsur-unsur rumusan tindak pidana sebagaimana yang didakwakan dalam surat dakwaan penuntut umum.

Menimbang, bahwa untuk menyatakan terdakwa bersalah maka keseluruhan unsur pasal yang didakwakan haruslah terpenuhi dari perbuatan para terdakwa.

Menimbang, bahwa para terdakwa diajukan di depan persidangan dengan dakwaan tunggal yaitu melanggar pasal 351 ayat (3) KUHP jo pasal 55 ayat (1) ke-1 KUHP, yang mana unsur-unsur pasal 351 ayat (3) adalah sebagai berikut:

1. Unsur Barang Siapa

Menimbang, bahwa unsur pertama yaitu "barangsiapa" yang dimaksud oleh undang-undang adalah subyek Hukum tanpa terkecuali, dan dalam hubunganya dalam perkara ini yang dimaksud sebagai subyek tindak pidana adalah orang yang mampu mempertanggung jawabkan setiap perbuatannya. Dalam hal ini adalah terdakwa I dan terdakwa II yang mana dalam keadaan sehat jasmani maupun rohani dan dihadapkan di persidangan sebagai para terdakwa/subjek tindak pidana yang didakwakan kepadanya, yang kebenaran identitasnya telah diakui oleh para terdakwa sendiri dan juga dibenarkan saksi-saksi, dengan demikian telah memenuhi unsur "Barangsiapa", sehingga unsur "barangsiapa" menurut majelis hakim telah terpenuhi. 


\section{Unsur Melakukan Penganiayaan}

Menimbang, bahwa menurut yurisprudensi yang dimaksud dengan penganiayaan adalah setiap perbuatan yang dilakukan dengan sengaja dan tanpa hak menyakiti dan melukai badan pada orang lain, atau dengan sengaja merugikan kesehatan orang lain atau menimbulkan perasaan tidak enak, rasa sakit atau luka pada orang lain, sehingga pengertian dengan sengaja. KUHP tidak memberikan batasan apa yang diartikan dengan sengaja, namun demikian dalam memorie van Toelichting (Mvt) mengartikan kesengajaan sebagai menghendaki dan mengetahui (Williens en wetens) sehingga sengaja di sini dapatlah menghendaki apa yang dilakukan itu, termasuk akibat yang ditimbulkanya.

Menimbang, bahwa dihubungkan dengan fakta yang terungkap di persidangan benar pada hari minggu tanggal 13 Januari 2013 sekira jam 13.00 WIB, di rumah para terdakwa di Dusun Waduk Desa Tlemang Kecamatan Ngimbang Kabupaten Lamongan, terdakwa I dan terdakwa II memukul korban dan awal kejadiannya ketika korban yang sedang kambuh gangguan jiwanya, sedang bertengkar dengan saudaranya yang bernama saksi, kemudian ditinggal pergi oleh saksi dan selanjutnya korban mengamuk dan pergi menuju rumah para terdakwa serta melempari rumah para terdakwa.

Menimbang, bahwa ketika korban sedang mengamuk terdakwa I saat itu sedang berada di kandang belakang rumah, karena takut terdakwa I masuk ke dalam rumah bersama terdakwa II dan mengunci semua pintu rumah dan tidak berapa lama kemudian korban menuju pintu samping rumah para terdakwa dan langsung mendobrak pintu yang telah dikunci dengan cengkal pintu dimana terdakwa I sudah berada di belakang pintu untuk memegang cengkal pintu agar pintu tidak bisa dibuka, namun karena dorongannya kuat terdakwa I seketika terjatuh karena pintu berhasil dibuka oleh korban. Mengetahui terdakwa I jatuh dan pintu berhasil didorong korban Matalim sambil membawa sabit dan mengayunkannya kepada terdakwa I, terdakwaII yang berada di dapur lalu memukul korban dengan paralon. Selajutnya korban berusaha memukul terdakwa II dan mengetahui hal tersebut. Terdakwa I langsung memukul korban menggunakan kayu cengkal pintu mengenai kepala bagian belakang 
sehingga korban terjatuh dan mengeluarkan darah dan benar kemudian para terdakwa berteriak minta tolong dan korban Matalim selanjutnya dibawa ke rumah sakit.

Menimbang bahwa akibat pukulan para terdakwa korban Matalim mengalami luka sebagaimana Visum el Repertum No. 449/43/413.105.29/2013 bertanggal 14 januari 2013 dari rumah sakit umum daerah Ngimbang Lamongan yang ditanda tangani dokter dengan kesimpulan: telah diperiksa seorang korban laki-laki bernama Matalim umur 48 tahun, jenis kelamin laki-laki, pekerjaan PNS, Alamat Dsn Waduk Ds Tlemang Kec Ngimbang Kabupaten LAMONGAN, pada pemeriksaan korban dalam keadaan tidak sadar (COMA). Reflek pupil menurun, terdapat luka robek $2 \mathrm{~cm}$ (kemungkinan benturan benda tumpul) dan setelah dirawat selama 5 hari di rumah sakit umum daerah Ngimbang Lamongan. Korban akhirnya meninggal dunia karena cedera otak berat.

Menimbang, bahwa berdasarkan fakta-fakta tersebut di atas majelis berpendapat bahwa para terdakwa setidaknya menyadari dan mengetahui bahwa pukulan yang dilakukan oleh terdakwa mengenai kepala merupakan bagian yang vital yang berakibat korban Matalim sakit/luka pada korban bahkan hingga meninggal dunia.

Menimbang, bahwa berdasarkan pertimbangan-pertimbangan di atas maka unsur "melakukan penganiayaan", dengan demikian telah terpenuhi.

3. Unsur Mengakibatkan Matinya Orang

Menimbang, berdasarkan fakta yang terungkap di persidangan bahwa terdakwa I dan terdakwa II telah melakukan pemukulan terhadap korban Matalim mengalami cedera pada kepala dan dirawat di Rumah Sakit Umum Daerah Ngimbang Lamongan sebagaimana diterangkan dalam visum et Repertum No./ 449/43/413.105/2013 tanggal 14 Januari 2013 dari RSUD Ngimbang yang ditandatangani oleh dokter dengan kesimpulan saksi korban dalam keadaan tidak sadar reflek pupil menurun, terdapat luka robek pada kepala bagian kiri P:7 cm, kepala bagian kiri terdapat luka memar dan robek $2 \mathrm{~cm}$ (kemungkinan benturan benda tumpul). Dan kemudian setelah dirawat 5 hari akhirnaya korban meningal dunia sebagiamana visum et Repertum No./ 449/43/413.105/2013 tanggal 17 Januari 2013 dari rumah sakit 
umum daerah Ngimbang Lamongan yang ditanda tangani dr Ik Mangagungdharma dengan kesimpulan: telah diperiksa seorang korban laki-laki, umur 48 tahun, jenis kelamin laki-laki, pekerjaan PNS, Alamat Dsn Waduk Ds Tlemang Kec Ngimbang Kabupaten Lamongan pada pemeriksaan jam 09.00 WIB tanggal 17 januari 2013 korban dinyatakan sudah meninggal disebabkan cedera otak berat setelah mendapat perawatan intensif selam 5 hari DiICU RSUD Ngimbang.

Menimbang, bahwa berdasarkan fakta tersebut di atas maka majelis berpendapat bahwa unsur "mengakibatkan matinya orang" telah terpenuhi.

Menimbang, bahwa penuntut umum dalam merumuskan dakwaannya memasukkan pasal 55 ayat (1) ke 1 KUHP yaitu peraturan hukum yang mengatur tentang penyertaan dalam melakukan perbuatan pidana, sehingga majelis hakim akan mempertimbangkannya penerapan pasal tersebut yang didakwakan kepadanya.

Menimbang, bahwa menurut pasal 55 ayat (1) ki 1 KUHP yang dapat dipidana sebagai pelaku (dader) suatu perbuatan pidana adalah orang yang melakukan, yang menyuruh melakukan atau turut melakukan.

Menimbang, bahwa untuk dapat dikatakan sebagai bentuk penyertaan adalah timbulnya kesadaran akan adanya kerjasama yang dilakukan oleh dua orang atau lebih yang sangat erat dan tangkap didalam melakukan suatu delik, dimana kerjasama tersebut haruslah secara terpadu baik secara psikis (intelektual) maupun secara materiil, dan untuk adanya suatu kerjasama tersebut adalah tidak perlu bahwa para pelaku tindak pidana sebelumnya telah memperjanjikan suatu kerjasama, akan tetapi cukup apabila pada saat tindak pidana dilakukan, setiap pelaku peserta mengetahui bahwa telah bekerja sama secara baik dan sadar, yang berarti setiap pelaku saling mengetahui dan menyadari tindakan para pelaku peserta lainnya, maupun secara langsung, yang berarti ada perwujudan dari tindakan para terdakwa tersebut.

Menimbang, bahwa berdasarkan fakta yang terungkap di persidangan, telah nyata bahwa pada saat korban datang ke rumah para terdakwa dan berusaha masuk melalui pintu samping, pada 
waktu itu terdakwa I berusaha memegang kayu cengkal agar korban tidak dapat masuk. Tapi korban tetap dapat masuk dengan mendobrak pintu. Seketika terdakwa I terjatuh, dan oleh karena korban Matalim membawa sebilah sabit sehingga terdakwa II memukul korban Matalim dengan paralon. Sehingga korban Matalim berusaha membalas terdakwa II, dan melihat hal tersebut terdakwa I kemudian memukul korban dengan kayu cengkal pintu mengenai kepala bagian belakang korban sehingga korban berdarah dan terjatuh.

Menimbang, bahwa berdasarkan fakta-fakta di atas, telah menunjukkan bahwa antara I dan II sebagai suami istri telah terjalin kerjasama secara terpadu dimana kerjasama tersebut dilakukan secara sadar sesuai dengan perannya masing-masing untuk saling menolong/membantu.

Menimbang, bahwa dengan demikian majelis hakim berpendapat bahwa para terdakwa berkualitas sebagai orang ynag melakukan perbuatan yaitu dengan sengaja mengerjakan terjadinya sesuatu, karena adanya kerjasama secara sadar dan adanya pelaksanaan bersama secara fisik.

Menimbang, bahwa dengan demikian penerapan pasal 55 ayat (1) KUHP juga telah terpenuhi.

Menimbang, bahwa terhadap pembelaan yang diajukan oleh penasihat hukum, para terdakwa yang pada pokoknya menyatakan bahwa para terdakwa tidak terbukti melakukan tindak pidana dan mohon dibebaskan. Majelis hakim berpendapat bahwa sebagaimana telah diuraikan sebelumnya bahwa para terdakwa telah terbukti melakukan tindak pidana dan perbuatan para terdakwa tersebut tidak dapat dikategorikan sebagai overmacht maupun noodweer-exces, karena dalam hal ini para terdakwa dapat lari/menghindar korban Matalim yang sedang mengamuk dan membawa sebilah sabit dengan keluar dari rumah melalui pintu depan atau setidak-tidaknya terdakwa melakukan pemukulan tidak pada organ vital korban yang dapat berakibat kematian. Sehingga demikian pembelaan dari penasihat hukum para terdakwa haruslah ditolak.

Menimbang, bahwa terhadap keterangan ahli yang menyatakan bahwa para terdakwa tidak dapat dimintai pertanggungjawaban pidana, karena ada unsur overmacht atau 
membela diri, majelis hakim menilai bahwa dari rangkaian peristiwa dalam fakta persidangan sedianya para terdakwa masih memiliki waktu meskipun sangat pendek untuk keluar dari pintu depan rumah dan tenaga yang digunakan oleh para pelaku sejumlah 2 orang sedangkan korban hanya seorang diri. Dan keterangan saksi $A$ de charge yang diajukan oleh penasehat hukum terdakwa di persidangan, kedua orang saksi tersebut tidak melihat kejadian dan hanya menerangkan latar belakang korban yang sering mengamuk sebelum kejadian karena ada gangguan jiwa, dengan demikian keterangan ahli dan keterangan saksi a de charge tersebut patut dikesampingkan.

Menimbang, bahwa selama pemeriksaan di persidangan majelis tidak menemukan alasan pembenar yang dapat menghilangkan sifat melawan hukum dan perbuatan terdakwa. Oleh karena itu terdakwa harus dinyatakan bersalah dan harus mempetanggungjawabkan perbuatannya serta dijatuhi pidana yang setimpal dengan perbuatannya.

Menimbang, bahwa proses penegakan hukum harus dilakukan secara tegas namun juga tetap mempertimbangkan aspek keseimbangan serta keadilan yang mana dalam kaitan ini majelis melihat perbuatan para terdakwa dilakukan karena korban menyerang ke rumah para terdakwa masuk ke dalam rumah dan tindakan para terdakwa tersebut merupakan kumulasi perbuatan korban yang selama ini sering mengamuk terhadap warga sekitar karena sakit jiwanya kambuh. Yang mana telah diterangkan dari RSUD Dr Soetomo yang menyatakan bahwa korban menderita gangguan jiwa berat. Sehingga warga menjadi ketakutan dan tidak mendapatkan solusinya atas masalah tersebut hingga terjadi peristiwa pemukulan tersebut.

Menimbang, bahwa dengan demikian majelis berpendapat menjadi adil dan patut apabila terhadap diri para terdakwa dijatuhi pidana yang setimpal dengan perbuatannya yaitu berupa pidana bersyarat.

Menimbang, bahwa sebelum sampai pada penjatuhan pidana, maka perlu dipertimbangkan hal-hal yang memberatkan maupun yang meringankan dari diri para terdakwa. Sebagai berikut : Hal-hal yang memberatkan:

1. Perbuatan para terdakwa menyebabkan orang lain meninggal dunia. 
Hal-hal yang meringankan:

1. Para terdakwa bersikap sopan dan belum pernah dihukum.

2. Para terdakwa mengakui kesalahannya dan menyesali.

3. Para terdakwa kondisinya sudah tua.

4. Perbuatan para terdakwa tersebut terjadi bukan semata-mata karena keinginan para terdakwa, akan tetapi dipicu saat korban kambuh gangguan jiwanya, mengamuk dan masuk ke dalam rumah para terdakwa.

Menimbang, bahwa berdasarkan pada hal-hal yang telah diuraikan di atas dengan memperhatikan secara seksama berbagai kepentingan dalam perkara ini, baik kepentingan para terdakwa dan keluarganya, majelis hakim berpendirian bahwa pidana bersyarat kepada para terdakwa yang dinantinya akan dijatuhkan sebagaimana amar dalam putusan ini adalah setimpal dengan kesalahannya.

\section{Amar Putusan Pengadilan Negeri Lamongan No :} 164/Pid.B/2013/PN LMG. tentang Tindak Pidana Penganiayaan yang Menyebabkan Korban Meningal Dunia.

Dalam memutuskan perkara No: 164/Pid.B/2013/PN.LMG tentang penganiayaan yang menyebabkan korban meninggal dunia, majelis hakim Pengadilan Negeri Lamongan berdasarkan pasal 351 (3) KUHP, dan berdasarkan pertimbangan-pertimbangan majelis hakim, selain itu keputusan juga diambil oleh majelis hakim pengadilan negeri Lamongan berdasarkan, bukti-bukti saksi-saksi, hasil visum et repertum yang dilakukan oleh dokter ahli, serta tuntutan jaksa penuntut umum.

Berdasarkan hal-hal tersebut di atas Pengadilan Negeri Lamongan memutuskan bahwa:

1. Menyatakan bahwa terdakwa I. dan terdakwa II. telah terbukti secara sah dan menyakinkan bersalah melakukan Tindak Pidana "Penganiayaan yang Menyebabkan Mati"

2. Menjatuhkan pidana terhadap para terdakwa oleh karena itu dengan pidana penjara masing-masing selama 5 (Lima) Bulan.

3. Memerintahkan bahwa pidana tersebut tidak perlu dijalani, kecuali kalau dikemudian hari dengan putusan hakim yang telah berkekuatan Hukum tetap diberikan perintah lain atas alasan para terdakwa sebelum atau sesudah percobaaan selama 8 (Delapan) bulan terakhir telah melakukan sesuatu tindak pidana. 
4. Menetapkan agar barang bukti berupa :

a. 1 (satu) buah sabit bergagang kayu.

b. 1 (satu) buah cengkal pintu bentuk bulat garis tengah $5 \mathrm{~cm}$ panjang $25 \mathrm{~cm}$ warna putih coklat.

c. 1 (satu) buah pipa paralon kecil garis tengah $2 \mathrm{~cm}$ panjang $25 \mathrm{~cm}$ warna abu-abu dirampas dan dimusnahkan.

5. Membebankan kepada para terdakwa untuk membayar biaya perkara masing-masing sebesar Rp. 2.500,00 (dua ribu lima ratus rupiah).

Demikian diputuskan dalam rapat permusyarawatan Majelis Hakim Pengadilan Negeri Lamongan pada hari Kamis tanggal 10 Oktober 2013 oleh hakim ketua majelis, dengan hakim anggota, putusan mana diucapkan dalam sidang yang terbuka untuk umum pada hari Kamis tanggal 17 Oktober 2013 oleh ketua majelis hakim tersebut dengan dihadiri oleh Hakim-Hakim Anggota tersebut dengan dibantu oleh panitera pengganti dan dihadiri oleh Jaksa penuntut umum pada kejaksaan Negeri Lamongan serta para terdakwa didamping penasehat hukumnya.

\section{Analisis Putusan Hukum Hakim tentang Tindak Pidana Penganiayaan yang Mengakibatkan Korban Meninggal Dunia dalam Putusan PN Lamongan No : 164/Pid.B/2013/PN LMG}

Penganiayaan adalah setiap perbuatan yang dilakukan dengan sengaja dan tanpa hak menyakiti dan melukai badan pada orang lain, atau dengan sengaja merugikan kesehatan orang lain atau menimbulkan perasaan tidak enak, rasa sakit atau luka pada orang lain, dalam kasus penganiayaan terkadang menimbulkan akibat yang fatal pada korban yaitu luka berat bahkan terkadang kematian.

Tindakan penganiayaan yang menyebabkan korban meninggal dunia ini terjadi pada putusan pengadilan negeri lamongan No; 164/Pid.B/2013?PN.LMG tentang penganiayaan yang menyebabkan korban meninggal dunia. Dalam memutuskan kasus ini, majelis hakim berpedoman dan menimbang kepada tuntutan jaksa penuntut umum yang menuntut para terdakwa dengan dakwaan tunggal yaitu melanggar pasal 351 ayat (3) KUHP Jo Pasal ayat (1) ke-1 KUHP. Bunyi dari pasal 351 (3) yaitu:

"Jika Mengakibatkan mati, diancam dengan pidana penjara paling lama 7 tahun" 
Dari ketentuan di atas, dapat diketahui bahwa unsur-unsur pada pasal 351 (3) tentang penganiayaan yang menyebabkan korban meninggal dunia adalah :

1. Unsur Barang siapa

Yang dimaksud "Barang Siapa" adalah manusia baik laki-laki maupun perempuan yang merupakan subyek Hukum yang diduga ataupun terdakwa melakukan tindak pidana.

2. Unsur Melakukan Penganiayaan

Menurut yurisprudensi, yang dimaksud dengan penganiayaan adalah setiap perbuatan yang dilakukan dengan sengaja dan tanpa hak menyakiti dan melukai badan pada orang lain, atau dengan sengaja merugikan kesehatan orang lain atau menimbulkan perasaan tidak enak, rasa sakit atau luka pada orang lain, sehingga pengertian 'dengan sengaja' KUHP tidak memberikan batasan apa yang diartikan dengan sengaja, namun demikian dalam memorie van Toelichting (Mvt) mengartikan kesengajaan sebagai menghendaki dan mengetahui (Williens en wetens) sehingga sengaja di sini dapatlah menghendaki apa yang dilakukan itu, termasuk akibat yang ditimbulkanya.

3. Unsur mengakibatkan kematian

Berdasarkan fakta yang terungkap di persidangan bahwa terdakwa I dan terdakwa II telah melakukan pemukulan terhadap korban mengalami cedera pada kepala dan dirawat di Rumah Sakit Umum Daerah Ngimbang Lamongan sebagaimana diterangkan dalam visum et Repertum No./ 449/43/413.105/2013 tanggal 14 Januari 2013 dari RSUD Ngimbang yang ditanda tangani oleh dokter dengan kesimpulan saksi korban dalam keadaan tidak sadar reflek pupil menurun, terdapat luka robek pada kepala bagian kiri P:7 $\mathrm{cm}$, kepala bagian kiri terdapat luka memar dan robek $2 \mathrm{~cm}$ (kemungkina benturan benda tumpul). Dan kemudian setelah dirawat 5 hari akhirnaya korban meningal dunia sebagiamana visum et Repertum No./ 449/43/413.105/2013 tanggal 17 Januari 2013 dari rumah sakit umum daerah Ngimbang Lamongan.

Berdasarkan semua unsur-unsur di atas, menurut majelis hakim semua unsur ada pada diri para terdakwa. Dan unsur yang paling dominan adalah matinya korban, dan semua unsur-unsur tersebut telah terbukti secara sah dan menyakinkan di depan hukum. 
Setelah menimbangkan tuntutan jaksa penuntut umum, dalam memutuskan perkara majelis hakim Pengadilan Negeri Lamongan juga mempertimbangkan hal-hal yang memberatkan dan meringankan para terdakwa antara lain.

Hal-hal yang memberatkan:

1. Perbuatan para terdakwa menyebabkan orang lain meninggal dunia Hal-hal yang meringankan:

1. Para terdakwa bersikap sopan dan belum pernah dihukum.

2. Para terdakwa mengakui kesalahannya dan menyesali.

3. Para terdakwa kondisinya sudah tua.

4. Perbuatan para terdakwa tersebut terjadi bukan semata-mata karena keinginan para terdakwa, akan tetapi dipicu saat korban Matalim kambuh gangguan jiwanya, mengamuk dan masuk ke dalam rumah para terdakwa.

Dalam memutuskan perkara selain berdasarkan pertimbangan pertimbangan majelis hakim, selain itu keputusan juga diambil oleh majelis hakim pengadilan negeri Lamongan berdasarkan, bukti-bukti saksi-saksi, hasil visum et repertum yang dilakukan oleh dokter ahli, serta tuntutan jaksa penuntut umum. Dan dalam kasus ini majelis Hakim pengadilan Lamongan memutuskan :

1. Menyatakan bahwa terdakwa I dan terdakwa II telah terbukti secara sah dan menyakinkan bersalah melakukan tindak pidana "penganiayaan yang menyebabkan mati"

2. Menjatuhkan pidana terhadap para terdakwa oleh karena itu dengan pidana penjara masing-masing selama 5 (lima) bulan.

3. Memerintahkan bahwa pidana tersebut tidak perlu dijalani, kecuali kalau di kemudian hari dengan putusan hakim yang telah berkekuatan hukum tetap diberikan perintah lain atas alasan para terdakwa sebelum atau sesudah percobaaan selama 8 (delapan) bulan terakhir telah melakukan sesuatu tindak pidana.

4. Menetapkan agar barang bukti berupa:

a. 1 (satu) buah sabit bergagang kayu

b. 1 (satu) buah cengkal pintu bentuk bulat garis tengah $5 \mathrm{~cm}$ panjang $25 \mathrm{~cm}$ warna putih coklat

c. 1 (satu) buah pipa paralon kecil garis tengah $2 \mathrm{~cm}$ panjang $25 \mathrm{~cm}$ warna abu-abu dirampas dan dimusnahkan. 
d. Membebankan kepada para terdakwa untuk membayar biaya perkara masing-masing sebesar Rp. 2.500,00 (dua ribu lima ratus rupiah).

Dalam kasus ini, dasar hakim dalam memutuskan perkara ini yang pertama adalah surat dakwaan dari jaksa penuntut umum, karena dalam hal ini hakim tidak bisa menjatuhkan keputusan yang keluar dari apa yang dituntutkan oleh jaksa penuntut umum. Selain itu dalam memutuskan perkara ini hakim telah mempertimbangkan di mana pada kasus ini korban yang menghampiri para terdakwa, dan korban pula yang pertama kali mencoba untuk memukul atau menyerang terdakwa, sehingga yang membuat para terdakwa menyerang atau melakukan pemukulan kepada para korban.

Dalam mengambil keputusan dalam pemberian sanksi hukum pada kasus ini majelis hakim juga mempertimbangkan 3 hal yaitu :

1. Kepastian

2. Kemanfaatan, dan

3. Keadilan.

Maksud kepastian hukum di atas adalah bahwa hakim telah memastikan bahwa perbuatan terdakwa telah melakukan tindak pidana dapat dihukum. Hakim menalarkan bahwa perbuatan terdakwa telah memenuhi unsur-unsur yang ada pada pasal yang telah ditetetapkan telah terpenuhi, karena tanpa adanya kepastian hukum bisa menunjukkan bahwa hakim telah sewenang-wenang dalam melakukan hukuman.

Untuk kemanfaatan hukum, hakim telah mempertimbangkan dengan membuat keputusan tersebut bisa menjadikan masyarakat luas maupun para terdakwa bisa menerima keputusan tersebut. Sedangkan untuk keadilan di sini hakim juga mempertimbangkan bahwa hukuman yang sudah didapat terdakwa sudah sesuai dengan tindakan para terdakwa, di mana terdakwa tidak pernah bermaksud melakukan tindakan pidana pemukulan itu, namun tindakan itu terjadi akibat korban yang menyerang duluan sehingga tindakan pidana itu terjadi.

\section{Pandangan Fiqh Jinâyah terhadap Putusan Pengadilan Lamongan No:164/Pid.B/2013/PNLMG tentang Penganiayaan yang Menyebabkan Korban meninggal Dunia.}

Berdasarkan deskripsi yang telah dipaparkan sebelumnya, sanksi hukum yang didakwakan kepada para terdakwa adalah 5 (Lima) Bulan 
penjara. Dengan dijerat pasal 351 ayat (3) KUHP Jo Pasal ayat (1) ke1 KUHP. Bunyi dari pasal 351 (3) yaitu :

"Jika Mengakibatkan mati, diancam dengan pidana penjara paling lama 7 tahun”

Namun pada putusan tersebut, hakim memerintahkan bahwa pidana tersebut tidak perlu dijalani, kecuali kalau dikemudian hari dengan putusan hakim yang telah berkekuatan hukum tetap diberikan perintah lain atas alasan para terdakwa sebelum atau sesudah percobaaan selama 8 (delapan) bulan terakhir telah melakukan sesuatu tindak pidana.

Penganiayaan yang dilakukan oleh para terdakwa dalam kasus ini berupa pemukulan terdakwa 1 dengan menggunakan cengkal pintu sebanyak 1 kali terhadap bagian belakang kepala korban dan pemukulan terdakwa II terhadap punggung korban menggunakan paralon sebanyak 3 kali di dalam fiqh jinâyah merupakan perbuatan jarîmah kejahatan terhadap selain jiwa di mana dalam hal ini perbuatan terdakwa I bisa dikatakan dengan dengan perbuatan jarîmah kejahatan terhadap selain jiwa (penganiayaan) yang bersifat pelukaan kepada muka dan kepala (alShajjal) dikarenakan melakukan perbuatan penganiayaan terhadap bagian belakang kepala korban. Sedangkan untuk terdakwa II yaitu melakukan perbuatan jarîmah kejahatan terhadap selain jiwa (penganiayaan) yang melakukan perbuatan penganayaan terhadap bagian punggung korban. Akibat dari pukulan kedua para tersangka inilah yang mengakibatkan korban tidak sadarkan diri dan meninggal dunia setelah dirawat 5 hari di RSUD Ngimbang Kabupaten Lamongan.

Dalam fiqh jinâyah, perbuatan para terdakwa yang melakukan penganiayaan yang mengakibatkan korban meninggal dunia yang diatur dalam pasal 351 ayat (3) KUHP Jo Pasal ayat (1) ke-1 KUHP. bisa dikatakan sama dengan jarîmah pembunuhan semi sengaja. Di mana dalam hal ini terdakwa pada saat pemukulan tidak bermaksud untuk membunuh korban. Tetapi korban meninggal akibat dari perbuatan terdakwa.

Namun peristiwa melakukan penganiayaan yang dilakukan oleh terdakwa ini pada dasarnya tidak dilakukan semata-mata karena keinginan para terdakwa, tetapi dikarenakan ulah korban yang menyerang dulu kepada terdakwa, sehingga terdakwa terpaksa melakukan itu untuk menyelamatkan diri. 
Dalam hal ini terdakwa tetap dikatakan telah melakukan perbuatan jarîmah pembunuhan semi sengaja, dikarenakan pada dasarnya korban meninggal dunia akibat dari perbuatan para terdakwa. Dikarenakan adanya sifat pembelaaan diri yang dilakukan oleh para terdakwa dalam menyikapi serangan korban, maka meskipun korban tetap dianggap bersalah telah melakukan perbuatan jarîmah pembunuhan semi sengaja, namun para terdakwa terbebas dari sanksi hukuman dari jarîmah pembunuhan semi sengaja.

Di dalam fiqh jinâyah, syarat-syarat dalam melakukan pembelaan diri adalah: ${ }^{32}$

1. Adanya serangan atau tindakan melawan hukum

Menurut syarat yang pertama ini, perbuatan yang menimpa orang yang diserang ini haruslah perbuatan yang melawan hukum. Apabila perbuatan tersebut bukanlah perbuatan yang melawan hukum, maka pembelaan atau penolakan tidak boleh dilakukan. Dengan demikian, pemakaian hak atau menunaikan kewajiban, baik oleh individu maupun oleh penguasa, atau tindakan-tindakan yang bolehkan oleh shara' tidak disebut sebagai serangan, seperti pemukulan oleh orang tua terhadap anaknya sebagai tindakan pengajaran atau pendidikan. Atau algojo yang melakukan tindakan potong tangan terhadap terhukum sebagai pelaksanaan tugas.

2. Penyerangan harus terjadi seketika

Syarat untuk dibolehkan melakukan tindakan membela diri adalah bahwa penyerangan harus terjadi seketika, dalam kasus perbuatan yang baru akan diserang saja merupakan perbuatan yang berlawanan dengan hukum. Hal ini oleh karena pembelaan baru boleh dilakukan apabila benar-benar telah terjadi serangan, atau diduga kuat akan terjadi, dengan perkataan lain terjadinya serangan itulah yang menjadikan pembelaan diri.

3. Tidak ada jalan lain untuk mengelakkan serangan

Syarat untuk diperbolehkannya pembelaan diri adalah bahwa tidak ada cara lain yang dapat dilakukan untuk menolak serangan kecuali dengan cara pembelaan tersebut, dengan demikan apabila masih ada untuk menolak serangan maka cara tersebut harus digunakan jadi kalau seseorang masih bisa menolak serangan dengan teriakan-teriakan, ia tidak perlu menggunakan pukulan senjata tajam

${ }^{32}$ lbid. 
yang bisa melukai, atau bahkan senjata api yang dapat membunuh orang yang menyerang. Apabila perbuatan tersebut telah dilakukan, padahal tidak diperlukan, perbuatan tersebut dianggap sebagai serangan dan jarîmah.

4. Penolakan serangan hanya boleh terjadi dengan kekuatan sepenuhnya.

Syarat yang keempat untuk dibolehkannya membela diri adalah bahwa penolakan hanya boleh menggunakan kekuatan seperlunya. Apabila penolakan tersebut melebihi batas yang diperlukan, hal itu bukan lagi disebut pembelaan melainkan penyerangan. Dengan demikian, orang yang diserang selamanya harus memakai cara pembelaan yang seringan mungkin, dan selam hal itu masih bisa dilakukan maka tidak boleh digunakan cara yang berat.

Dari pemaparan di atas tentang pembelaan diri, penulis berpendapat bahwa keempat syarat dalam pembelaan diri dalam fiqh jinâyah, telah terpenuhi pada diri terdakwa. Di mana dalam kasus ini perbuatan korban yang menyerang para terdakwa dengan menggunakan sabit dan serangan tersebut merupakan hal yang terjadi, bukan belum terjadi. Itulah yang membuat terdakwa menyerang karena tidak ada cara lain lagi dan dalam melakukan serangan juga tidak berlebihan meskipun mengenai pada bagian yang fatal yaitu kepala korban. Meskipun dalam hal ini korban yang menyerang adalah orang yang sedang kambuh gangguan jiwanya.Tetapi perbuatan terdakwa tetap dianggap sebagai perbuatan yang melawan hukum dan juga membahayakan jiwa dari para terdakwa.

Sedangkan sanksi dari perbuatan terdakwa yang melakukan penganiayaan yang mengakibatkan korban meninggal dunia dalam hukum Islam disamakan dengan pembunuhan semi sengaja adalah diancam dengan hukuman pokok berupa hukuman diyât dan kafârat. Dalam hal ini meskipun diyât dan kafârat menjadi hukuman pokok hukuman dari pembunuhan semi sengaja, namun ketika para terdakwa tidak mempunyai harta untuk membayar diyât sebagai penebus dosanya, maka diberlakukan hukuman ta'zîr sebagai hukuman pengganti. Dalam hukuman ta'zîr ini, hakim diberikan kebebasan untuk memutuskan hukumannya. Namun pada kasus ini karena para terdakwa melakukan perbuatan ini dikarenakan ada unsur pembelaan diri, maka secara tidak langsung para terdakwa terbebas dari pertanggungjawaban pidana. 
Meskipun pada dasarnya akibat perbuatan pembelaan diri dengan cara pemukulan yang dilakukan oleh terdakwa mengakibatkan korban meninggal dunia.

Dalam Islam tujuan pemberian hukuman sesuai dengan konsep tujuan umum disyariatkan hukum yaitu untuk merealisasikan kemaslahatan umat sekaligus menegakkan keadilan. Hukum yang ditegakkan dalam dalam syariat Islam mempunyai dua aspek yaitu:

1. Preventif (pencegahan)

2. Edukatif( pendidikan)

Dengan ditetapkan kedua aspek tersebut akan dihasilkan satu aspek kemaslahatan, yaitu terbentuknya moral yang baik, maka masyarakat menjadi aman, tentram, damai dan penuh dengan keadilan, karena moral yang dilandaskan agama akan membawa perilaku manusia sesuai tuntutan agama.

Sesuai dengan tujuan pokok menurut syariat Islam ialah demi tercapainya kemaslahatan bagi individu dan masyarakat, dengan demikian hukum yang baik adalah:

1. Harus mampu mencegah seseorang dari perbuatan maksiat.

2. Batas tertinggi dan terendah suatu hukuman tergantung kepada kemaslahatan masyarakat. Apabila kemaslahatan menghendaki beratnya hukuman, maka hukuman diperberat, demikian pula sebaliknya masyarakat menghendaki ringannya hukuman, maka hukuman diperingan

3. Memberikan hukuman kepada orang yang melakukan kejahatan itu bukan untuk maksud membalas dendam. Melainkan sesungguhnya untuk kemaslahatannya.

4. Hukuman adalah upaya terakhir dalam menjaga seseorang supaya tidak jatuh kepada suatu maksiat.

Seperti telah disebutkan di atas bahwa sanksi putusan pengadilan negeri lamongan 5 bulan kepada para terdakwa. Dan para terdakwa juga tidak perlu untuk menjalani hukuman tersebut.Kecuali apabila dalam sesudah atau sebelum masa percobaan 8 bulan para terdakwa kembali melakukan perbuatan pidana. Dalam hal ini hukuman tersebut dinilai sudah tepat dikarenakan penganiayaan atau pemukulan tersebut terjadi akibat dari korban yang menyerang kepada para terdakwa terlebih dahulu. 
Meskipun para terdakwa hanya diberlakukan hukuman bersyarat di mana tidak perlu menjalani hukuman meskipun dalam pengawasan hukum apabila para terdakwa di kemudian hari bila melakukan tindak pidana, maka akan langsung dihukum sesuai dengan apa yang diputuskan hakim, sesuai dengan tujuan dari hukum pidana Islam, yaitu mendidik dan pencegahan akan tercapai di mana terdakwa akan berpikir lagi ketika akan melakukan tindak pidana apapun. Dikarenakan terdakwa ada dalam pengawasan Hukum. Dimana ketika terdakwa melakukan tindakan pidana, maka terdakwa akan langsung dimasukkan kedalam penjara berdasarkan keputusan hakim yang telah berkekuatan Hukum.

\section{Simpulan}

Putusan hukum hakim dalam putusan No:164/Pid.B/2013/PN LMG tentang tindak pidana penganiayaan yang menyebabkan korban meninggal dunia yang menjadi dasarnya adalah dakwaan dari jaksa penuntut umum, dan terpenuhinya unsur-unsur dalam dakwaan tersebut. Dikarenakan tanpa dakwaan jaksa penuntut umum dan unsurunsurnya terpenuhi, maka hakim tidak bisa menghukum terdakwa. Sedangkan untuk putusan pada perkara ini, hakim dalam memutuskan putusannya mempertimbangkan 3 hal yaitu kepastian, kemanfaatan dan keadilan. Hakim memutuskan menghukum para terdakwa dengan penjara masing-masing 5 bulan, dengan ketentuan para terdakwa tidak perlu menjalani hukuman kecuali kalau dikemudian hari dengan putusan hakim yang telah berkekuatan hukum tetap diberikan perintah lain atas alasan para terdakwa sebelum percobaan selama 8 (delapan) bulan terakhir telah melakukan sesuatu tindak pidana.

Hukum Penganiayaan dalam kasus No:164/Pid.B/2013/PN. LMG yang mengakibatkan korban meninggal dunia dalam tinjauan Hukum pidana Islam (fiqh jinâyah) dapat disamakan dengan melakukan pembunuhan semi sengaja, dimana dalam melakukan penganiayaan pelaku sengaja tetapi tidak berniat untukmembunuh korban. Sedangkan untuk sanksinya hukuman pokoknya berupa hukuman hukuman diyât dan kafârat, sedangkan untuk hukuman pengganti berupa hukuman ta'zîr sedangkan dalam kasus ini para terdakwa tidak dikenakan hukuman apa-apa. Dikarenakan pemukulan yang dilakukan oleh para 
terdakwa sebagai upaya untuk membela diri dikarenakan korban menyerang dulu.

\section{Daftar Rujukan}

Ahmad, Hanafi. Asas-asas Hukum Pidana Islam. Jakarta: NV Bulan Bintang, 1990.

Ahmad, Muslich Wardi. Pengantar dan Asas Hukum Pidana Islam (Fikih Jinayah). Jakarta: Sinar Grafika, 2004.

Amirin, Tangtang Amin M. Menyusun Rencana Penelitian. Jakarta: CV. Rajawali, 1990.

Audah, Abd Qadir. at-Tashrî̀ al-Jinầî al-Islâmî. Beirut: Dar al-Kitab al 'arabi, tt.

Depag. Al-Qur'an dan Terjemahannya. Semarang: Cv Adi Grafika Semarang, 1994.

Djazuli, A. Fiqh Jinayah, (Upaya Menanggulangi Kejahatan dalam Islam). Jakarta: PT Raja Grafindo Persada, 2000.

HM, Soeharto. Hukum Pidana Materiil Unsur-Unsur Obyektif Sebagai Dasar Dakwaan. Jakarta: Sinar Grafika, 1993.

Leden, Marpaung. Tindak Pidana Terhadap Nyawa dan Tubuh. Jakarta: SinarGrafika, Cetakan III, 2005.

Makhus, Munajat. Dekontruksi Hukum Pidana Islam. Yogyakarta: LogungPustaka, 2004.

Marsum. Fiqih Jinayat (Hukum Pidana Islam). Yogyakarta: BAG. Penerbitan FH UII, 1999.

Marzuki, Mahmud Peter. Penelitian Hukum. Jakarta: Kencana Media Group, 2010.

Moeljatno. Kitab Undang-Undang Hukum Pidana. Jakarta: Bumi Aksara, 2012.

Mubarok, Jaih. Asas-asas Hukum Pidana Islam. Jakarta: Anggota Ikapi, 2004.

R, Soesilo. KUHP serta Komentar Lengkap. Bogor: Politea, t.th.V

Rahmat, Hakim. Hukum Pidana Islam. Bandung: CV. Pustaka Setia, 2000.

Rusyd, Ibnu. Bidâyah al-Mujtahid, terj. A. Abdurrahman, A. Haris,.

Sabiq, Sayyid. Fiqh al-Sunnah, terj. A. Ali. Fiqih Sunnah jilid 10. 
Waluyo, Bimbingan. Penelitian Hukum dalam Praktek. Jakarta: Sinar Grafika, 1996.

Wirjono, Prodjodikoro. Asas-Asas Hukum Pidana di Indonesia. Bandung: PT Eresco, 1486.

Wahyudi, Eko. "Tindak Pidana Penganiayaan", Skripsi-IAIN Sunan Ampel, 2005.

Susanto, M Iman. "Tinjauan Fiqh Jinayah terhadap Penganiayaan yang Berakibat Luka Berat dan Sanksi Hukumnya; Studi Analisis terhadap Pasal 90 jo Pasal 354 KUHP”, Skripsi-IAIN Sunan Ampel, 2009.

Aisyah, Tumoro Ikayanti. "Studi Yuridis terhadap Sanksi Hukum Putusan Pengandilan Negeri Sidoarjo NO:77/Pid.B/2007PN.SDA”. Skripsi-IAIN Sunan Ampel, 2007.

Usamah. "Pertanggungjawaban Pidana Perspektif Hukum Islam". TesisUniversitas Sumatera Utara, 2008.

http//boxriborn.blogspot.com/2013/08/pengertian-dan-macam-macamjinayah_5383.html?m= diaksestgl 6 Juli 2014

http;//elanlan.wordpress.com/2009/10/22/memahamikedudukan-azirdalam-fiqh-jinayah, diaksestglpada 4 juli 2014

http//lahut.blogspot.com/2011/04/tindak-pidana-penganiayaan.html diakses tgl 13 april 2014

http//raypratama.blogspot.com/2012/02/pengertian-dasar-hukum-dansyarat.html/m=1 diakses tgl 5 juli 2014 